\title{
Strength of the Tolerance in the Country Through the Tepaslira Directed to the Community Java in Surakarta
}

\author{
Novia Wahyu Wardhani \\ Universitas Negeri Semarang \\ Semarang, Indonesia \\ noviawahyu@mail.unnes.ac.id
}

\author{
Sabar Narimo \\ Universitas Muhammadiyah Surakarta \\ Surakarta, Indonesia \\ sabar.narimo@ymail.com
}

\begin{abstract}
Tolerance is a condition that needs to be preserved in heterogeneous society. Nowadays, tolerance has stated to fade in the life of society that it needs to be reminded and reinforced that this nation has local wisdom which teaches the beauty of tolerance between ethnicities, between religions, between groups and between regions in order to achieve consistent, harmonious, and balanced in society, national and state life. One of the local wisdoms which can be re-explored is Tepaslira. This research aims to describe how Tepaslira is implemented in the life Javanese community which keeps on being preserved by the Javanese community in Sudiroprajan Surakarta. This research is qualitative research with ethnographic approach. The data was obtained through observation, interview, and documentation while the data analysis used was interactive model analysis. The result shows that the life of the heterogeneous community there which has two ethnicities namely Javanese-Chinese and three religions namely Christian-Islam-Confucianism goes well because the community still hold Tepaslira in high regard.
\end{abstract}

Keywords—culture; sudiroprajan; tepaslira; tolerance

\section{INTRODUCTION}

Javanese culture which promotes social peace and harmony and obviously has cultural values that supports it, one of which is tepa sarira (tepaslira) [1]. Tepaslira is an individual attitude to control oneself based on self-awareness which makes the society able to position themselves in social interaction structure based on self-decision and willingness [2]. Javanese people who have tepaslira principle can interact well in their neighborhood. Javanese culture which is strongly associated with tepaslira, makes Javanese people think twice when they want to do something that disturb the harmony and relationship with others [3]. As the saying found during observation and interview on January $25^{\text {th }} 2017$ goes "Yen dijiwit iku krasa lara ya aja njiwit liyan" (if it feels painful when we get pinched, then we should not pinch others).

Tepaslira has different forms based on the situation and condition of the community in their neighborhood interaction. One form of tepaselira implementation is in kampung (village) Sudiroprajan. Sudiroprajan is a kampung "Pecinan" (Chinatown) which is well known as kampung Balong, a kampung which is resided by Tionghoa ethnicity, during colonial era. They had to build a ghetto (special residence), which by the colonials was intended to isolate and severe the contact with other residents [4]. The establishment of the ghetto is very reasonable, because the history has proven that inter-ethnic conflict and tension had happened many times which have the potential to develop into communal violence.

Those racism and communal violence were happened frequently, some of the causes are social-economic gap, business competition, ideology competition, religion and other intolerance, which triggers some cases of anti-Tionghoa violence. These conflicts and tensions turned out that it can be mitigated by addressing it wisely, hold pluralism in high regard which is based on the comprehension of Pancasila in community, nation and state life and tepaslira culture becomes the key of peace and harmony of inter-ethnic life.

Tepaslira becomes very important to be re-explored considering that tolerance is getting eroded. Several examples of conflict cases in Indonesia such as conflict of interest, conflict between native and non-native, inter-groups conflict, and inter-ethnic conflict. The examples of inter-ethnic conflicts such as conflict in Aceh, Sambas, Madura, Papua and China become one of the indicators of the erosion of tolerance

This article tries to describe the condition of Sudiroprajan community who have strong tepaslira culture in every activity of their life. The Tepaslira culture can be used as an example in establishing multicultural interaction which is full of tolerance in order to create harmony in society, nation and state life.

\section{RESEARCH METHOD}

This research uses qualitative method with ethnographic approach directed towards the results of ethnic and emic views of the researcher and people of Sudiroprajan, Surakarta. The data are obtained through observation, interview, and documentation. The obtained data are primary and secondary ones. Observation is used to allow the researcher to directly watch the forms of tepaslira existing and growing in the society. To explore what has been seen, the researcher collects some information from the informants be it elderly or young ones, Javanese, Chinese or mixed ones, culture experts, public figures, religious figures, and academicians, and they are all equipped with some documentation. The data are analyzed using interactional model analysis until the data are saturated, 
i.e. no new data are obtained. The analysis activity includes data reduction, data display, conclusion drawing, and verification.

\section{RESULTS AND DISCUSSION}

\section{A. Collective Memory of Javanese People}

It is undeniable that the collective memory of Javanese people of ethnic conflict, the Chinese-Javanese one, will not disappear. Even scientiests had recorded the conflict in history. Such is what the elderly and humanist of Kraton Surakarta, KPA. Furthermore, it is said that when the ethnic conflict emerging in Batavia (1740) had spread to the Kraton Kartasura's region and devastated the Kraton and even forced the King Pakoe Boewono II flee to Ponorogo, the Chinese named Raden Mas Gerendi or Sunan Kuning (or Yellow Sunan as the ones naming him the King were people of yellow skin) the King and he assumed the title Amangkurat V. This rebellion could be ended (thanks tothe help from VOC) when the King Pakoe Boewono II returned from exile, six months later. De Klerck, in History of Nederlands Indies, described that initially Pakoe Boewono II together with the Chinese attacked the hegemonic VOC in Central Java. However, when he lost the battle against the Dutch which was helped by Cakraningrat IV, Pakoe Boewono II changed side to support VOC, and the Chinese army thought they were betrayed and decided to attack Kraton Kartasura [5].

The same is also stated by Tan Giok Nio. He says that the friction of behavior influenced by socio-economic gap in 1980s had resulted in anti-Chinese conflict, particularly in Surakarta (Mesen-Jl. Urip Sumoharjo) and the conflict spread even further to other regions in Central Java. According to Koh Tan, the psychological recovery for the minority who were the victims (such as those thrown with stone, or whose properties set in fire, destroyed) had gone well, even though in several place along Jalan Urip Sumoharjo the traces of such damages are deliberately left untouched to serve as part of memory and for reflection.

The May 1988 tragedy had been a moment Tan Kim Ing in particular and the Chinese in general would never forget. At that time, many Chinese became victims of raid, rape, arson, and murder, as a result of socio-economic imbalance and it was the peak of resistance towards the Chinese hegemony. The racism and violence against the Chinese ethnic were inevitable. In his opinion, it is indeed necessary to discuss and find common understanding and awareness between the Chinese and locals, to prevent any gap, let alone conflict from occurring. Ethnic acculturation, tolerance and combining the culture as well as shared philosophy of life can be a robust stake in anticipating any inter-ethnic tension and conflict.

\section{B. Acculturation of Sinuhun Pakoe Boewono X Legacy}

The Javanese-Chinese cultural acculturation in Sudiroprajan Subdistrict was the heritage to be built by Pakoe Boewono X, the King of Kraton Kasunanan Surakarta (18931939). For tens and even hundreds of years the Chinese descendants had inhabited and lived in coexistence with the Javanese. They organized a mix-marriage between the ethnics and gave birth to a new generation, a new culture and a new tradition.

The cultural acculturation began when Pakoe Boewono X's teapot lid fell around the bridge in Sudiroprajan village. People tried to find the lid, doing some wungon (night search) on a cemented bench at the edge of the bridge. They came from all groups, including the Javanese and Chinese, employers and employees, merchants and commoners. All worked together, breaking the imaginary wall which had prevented them from communicating with each other [5].

As time went, this activity became a routine. Another activity was added such as cokekan (Javanese traditional music) performance, wedangan (drinking tea, coffee, ginger). To the site lanterns and Chinese accessories were added. They did this by upholding the tepaslira (respecting, understanding, recognizing one another) philosophy. They socialized in diversity, forgetting the differences, building cultural acculturation, and organizing inter-ethnic mix marriage, and then a new civilization was born.

\section{Ethnical Acculturation and Mixed Descendants Cultural Blend}

Sudiroprajan is a subdistrict located at the heart of the city. It was once a rural area. Due to the regional development, its location is now in the middle of the town. Therein, a village called Balong exists. Most residents of this village are descendants of Chinese ethnic (known as Balong Chinese). They have been living for tens of years' side by side with Javanese ethnic along with the characters and cultures accompanying them. They coexisted in harmony and concord, sharing the teposliro philosophy, which meant to respect, acknowledge, understand each other towards a harmonious, concordant and well-balanced life.

These two ethnics are harmonious not only in terms of their culture, they even organize marriage between the two ethnics, which then create a new generation. They are aware that the coexistence with different ethnics is vulnerable to friction and conflict when the tolerance is not strong enough. The awareness of tolerance in a heterogenous community is extremely important. The many differences with no acceptance will easily trigger conflicts. If tolerance is not practiced and taught as early as possible, then the heterogeneity in life will only create more and more inconveniences and insecurities.

Sudiroprajan people have relatively high heterogeneity. This can be seen from the fact that they have two main great ethnics in Javanese and Chinese, three great religions in Islam, Christianity, and Confucianism, and two groups of community, the native and migrant inhabitants. While they are fairly plural, their tolerance for differences are really good. This can be seen from several activities they organize in their lives, including grebeg Sudiro, which have been practiced from tens of years ago.

\section{Tepaslira and Ora Obah Ora Mamah Philosophies}

In Indonesia in general and Java in particular, there is this value which is regarded as capable of nurturing tolerance in the society. It is the tepaslira principle. The tepaslira which was 
taught by the Javanese ancestors since long ago can actually be applied by Sudiroprajan people, a community of Chinese who came and lived there. Sudiroprajan people are not a society without conflict, yet any conflict based on cultural differences can be said as nearly non-existent. Their conflicts are mostly based on economic status. The villages in Sudiroprajan Subdistricts are mostly formed based on their economic status such as Mijen, Kepanjen, Sama'an, Balong, Sudiroprajan, and Limusan. Their acceptance of these diverse cultures can be seen from the architecture style, customs during religious holiday, marriage customs, and other cultural events.

Interestingly, as suggested by Sugiyo, a public figure, Sudiroprajan village has a custom/tradition they have organized for years, i.e. grebeg Sudiro. Grebeg Sudiro is a celebration to welcome the Chinese new year which combines the Chinese-Javanese cultures. Grebeg is the Kraton's tradition in welcoming religious holidays, such as grebeg Mulud (commemorating the birthday of Prophet Muhammad PBUH), Grebeg Pasa (Shawwal 1st), and Grebeg Besar (10 Dhu alHijjah). Grebeg Sudiro is commemorated seven days before the Chinese new year's celebration, being named after Sudiroprajan's name, characterized by the march of two gunungan, the fruit and vegetable Gunungan (in Javanese tradition, it symbolizes prosperity) and the Gunungan made of thousands of nian gao cake (as a manifestation of Chinese culture). Both of these gunungans are marched from the gate of Pasar Gede (Pasar Hardjonagoro - Yasan dalam Ingkang Sinuhun Kanjeng Susuhunan Pakoe Boewono Kaping X 18931939) and it ends at Klenteng Tien Kok Sie. This grebeg convey a message to the society to maintain the harmony between people of different faiths and ethnics and it is followed by traditional art performances from both ethnics including Pasukan Kraton, Turangga Seta, Reog, Jathilan, batik carnival, Barongsai, Liong, Taichi, Wushu, and people dressing like such characters as Sun Wukong, Ti Pat Kay (Zhu Bajie), Tang Sanzang, and several dan ladies dressed in Chinese goddesses. These indicate the extensive Javanese-Chinese cultural acculturation. According to Bul Hartono, Grebeg Sudiro serves the purpose of illustrating assimilation of Javanese-Chinese ethnics and cultures, expanding to include such aspects as traditions, arts, sports, health services and economy. Grebeg symbolizes the effort of bridging diversities towards unity through tepaslira or mutual respect, acknowledgement and togetherness.

The two gunungan marched in this grebeg tradition illustrates the gratitude to God the Almighty for what He has provided, including the lives and anything needed to support those lives, yet mankind should still strive to fulfill their needs for lives, such is said by Koh Liem (Suparwanto). He explains further that the gunungans upon their marches are provided to the people in general for being fought over. They are allowed to get as many as possible items from them. The philosohy underlying this is the Ora obah ora mamah wisdom, meaning people should keep trying to fulfill their needs. People's needs will never be self-fulfilled; they have to strive to fulfill them. Such is what life is all about. Tepaslira and Ora obah ora mamah are the representation of both ethnics in building harmony, concord, conformity, and coexistence in diversity.

\section{CONCLUSION}

History has recorded that the relationship between Javanese and Chinese people fluctuated since the Geger Pecinan incident in 1740. The Chinese community was localized in a ghetto by the colonial government to isolate them and disconnect their contact with others. Nowadays, the frictions between ethnics are mostly influenced by socio-economic gap, resulting in ethnic conflicts in many places.

The Javanese-Chinese community in Sudiroprajan subdistrict, Jebres, Surakarta Municipality build a new society, by acculturating their arts, cultures, and beliefs and organizing a mix marriage, shaping a new civilization based on tepaslira philosophy. The tepaslira philosophy can actually unite cultures, traditions, and civilizations, building harmonious, concordant and congenial society based on unity in diversity.

This cultural acculturation is manifested in Grebeg Sudiro, which combines the Javanese-Chinese culture in a new tradition, wrapped in inter-ethnic togetherness based on ora obah ora mamah philosophy.

\section{REFERENCES}

[1] F. Andani, Language Choice used by Street Seller in Bunderan GKB Gresik (Doctoral dissertation, UIN Sunan Ampel Surabaya), 2014.

[2] F.M. Suseno, Etika Jawa: Sebuah Analisa Falsafi tentang Kebijaksanaan Hidup Jawa, Jakarta : PT Gramedia Pusat, 2001.

[3] T. Wulandari, "Kultur Jawa Vs Kultur Barat (Kajian atas pengaruh kultur Jawa dan kultur Barat terhadap kemiskinan)," DIMENSIA, vol. 5, no. 1, Yogyakarta: UNY, Maret 2011

[4] N. Sabar, Butir-butir Budaya Jawa: Perilaku dan Pengendalian Diri, Surakarta: Wahyu Saksama, 2009.

[5] K. Winarno, Kajian rutin Serat Wulang-Reh. Makalah disajikan dalam Sarasehan Basa Jawi, Sanggar Pasinaon Basa Jawi Sabar Narimo. Di Surakarta, 2009 